\title{
RECYCLING OF MINERAL SERPENTINITE WASTE FROM MINING INDUSTRY AND ITS USE IN AGRICULTURE TO IMPROVE SOIL AGROCHEMICAL PROPERTIES
}

Juozas PEKARSKAS, Institute of Environment and Ecology, Faculty of Forest Sciences and Ecology, Aleksandras Stulginskis University, Studentu str. 11, Academy, Kaunas r., 53361 Lithuania, juozas.pekarskas@asu.lt

Algirdas GAVENAUSKAS, Institute of Environment and Ecology, Faculty of Forest Sciences and Ecology, Aleksandras Stulginskis University, Studentu str. 11, Academy, Kaunas r., 53361 Lithuania, algirdas.gavenauskas@ asu.lt

Anželika DAUTARTE், Institute of Environment and Ecology, Faculty of Forest Sciences and Ecology, Aleksandras Stulginskis University, Studentu str. 11, Academy, Kaunas r., 53361 Lithuania, anzelika.dautarte@asu.lt (corresponding author)

Aida STIKLIENE், Institute of Environment and Ecology, Faculty of Forest Sciences and Ecology, Aleksandras Stulginskis University, Studentu str. 11, Academy, Kaunas distr. LT-53361. E-mail: aida.stikliene@asu.lt

\begin{abstract}
The influence of processing the serpentinite quarry from the Caucasian mountains at the foot of the Mount Elbrus crushed waste on soil agrochemical properties, phytotoxicity of spring barley, influence on barley plant biomass and its chemical composition were investigated. Ground and granular serpentinite had a different effect on soil and plants. Application of serpentinite fertilizers significantly increased the content of calcium, iron, 227.95-376.75 and 5.05-9.62 $\mathrm{mg} \mathrm{kg}^{-1}$, total and plant-derived magnesium $0.34-$ 0.52 and $1.19-2.16 \mathrm{mg} \mathrm{kg}^{-1}$, lead and nickel, while the amount of copper dropped substantially; the soil was becoming more alkaline. Application of ground serpentinite lead to alkalizing of the soil much more compared to the granular, with a significant increase in plant-derived magnesium. The influence of serpentinite increased the yield of spring barley plants in green and dry mass by 0.049 0.256 and $0.011-0.046 \mathrm{~g}$ or $0.65-3.41$ and $1.19-2.59 \%$ out of the growing vessel, and dry matter increased by $0.12-0.26 \%$ units, the yield of spring barley green and dry mass under the influence of ground serpentinite was higher than of granular serpentinite fertilizer, and the dry matter was found to be significantly higher than that of unfertilized spring barley plants. Ground and granular serpentinite was not phytotoxic to spring barley. An application of ground serpentinite increased an amount of calcium, potassium and magnesium in the barley dry matter compared to the granular serpentinite. Ground and granular serpentinite reduced the amount of trace elements copper and manganese in the dry mass of the plant, and the amount of zinc decreased only after fertilization with granular serpentinite. An application of serpentinite significantly decreased content of lead, chrome and cadmium while nickel content significantly increased in the dry matter of barley plants.
\end{abstract}

Keywords: serpentinite, soil agrochemical properties, spring barley, phytotoxicity, chemical composition

\section{INTRODUCTION}

Serpentinite (magnesium hydrosilicate) $\left(\mathrm{Mg}_{6}\left[\mathrm{Si}_{4} \mathrm{O}_{10}\right] \cdot[\mathrm{OH}]_{8}\right.$ or $3 \mathrm{MgO} \cdot 2 \mathrm{SiO}_{2} \cdot 2 \mathrm{H}_{2} \mathrm{O}$ ) has a volcanic origin and formed as a result of rock serpentinization processes comprising minerals antigorite, lizardite, calcite and chlorite. It is very rich in magnesium, there the amount of $\mathrm{MgO}$ may be up to $40 \%$ and higher. Serpentines are very rich in other elements that are important for plants also (Andreani et al., 2008; Boudier el at., 2010; Harrison, Rajakaruna, 2011; Deschamps et al., 2012). The chemical composition of serpentinite varies greatly and depends on the place of extraction. Frequently increased levels of B, Sr, Ba, Cs, As, Be, Li, Cl and other elements are found (Bonati et al., 1984; Hattori, Guillot, 2003, 2007; Tenthorey, Hermann, 2004; Deschamps et al., 2011).

Serpentinite is used as an ornamental mineral in the decoration of buildings, in construction, as a raw material in the chemical, metallurgical, fertilizer, highly resistant products industry, as a raw material for the production of sorrel cement, and also used as an additive for animal feed, in water and gas purification. It occupies an intermediate position in the classification of decorative stones between marble and semi-precious stones (ruby, sapphire, agate, onyx). Due to the amount of magnesium, it raises an interest of the fertilizer industry and agriculture as a source of magnesium for agricultural crops (Harrison, Rajakaruna, 2001; Ilyina, 2013; Lee, Soh, 2016).

Serpentinite has been tried in many countries as a magnesium rich soil improver to improve soil properties and fertilize agricultural crops because magnesium is a very important element of plant nutrition - an integral part of chlorophyll and is the only metal that is part of the chlorophyll content, an essential element of photosynthesis. It is vital

Copyright (C) 2017 The Authors. Published by Aleksandras Stulginskis University. This is an open-access article distributed under the terms of the Creative Commons Attribution License (CC-BY 4.0), which permits unrestricted use, distribution, and reproduction in any medium, provided the original author and source are credited. 
for the formation of chlorophyll. A portion of magnesium is involved in the synthesis of enzymes. In plants it is in the composition of pectinates and phytin (Skinner, 2005, Roemheld, Kirkly, 2007; Verbruggen, Hermanns, 2013; Senbayram et al., 2015).

Serpentinite has no significant effect on the yield of perennial grasses, but significantly increase the magnesium concentration in the grass dry matter, which reduces the risk of hypomagnesaemia in cattle. It has been found that serpentinite can substitute more soluble magnesium fertilizer (Chittenden et al., 1967; Haynly et al., 2005). The research carried out in Lithuania showed that granular serpentinite significantly increased the total, marketable seed and fodder potato tubers yields of one shrub (Pekarskas et al., 2017). Granulated serpentinite fertilizers significantly increased the yield of spring wheat grains and the 1000 grain weight compared to unfertilized wheat (Pekarskas, Šapranauskas, 2017).

The greatest impact on the change of magnesium in the soil has its acidity, texture and genetic soil type. Most of the soils in Lithuania are high in magnesium $(61 \%)$, and there are very low and low magnesium soils (17.1\%). The least of these soils (5.9\%) are in central Lithuania, mostly in the western (26.7\%) and eastern (23.8\%) part. Lowest amounts of magnesium consist in very and moderate acidic soil, much more in soils with $\mathrm{pH}>6.1$. In sandy and submerged soils content of magnesium is much lower than in clay loam and clays (Mažvila, 1998, Mažvila et al., 2011). It is appropriate to consider the amount of mobile magnesium in the soil while planning agricultural crops fertilization with magnesium fertilizers. The plants need to be fertilized if mobile magnesium presented low or very low in soil. Obtaining higher yields and growing plants demandable to magnesium crops can be fertilized when the soil in the mobile magnesium is moderate or high. (Staugaitis, Vaišvila, 2015).

The use of serpentinite is often limited by the concentration of toxic heavy metals in it. The use of serpentinite as a soil improver may be limited by the increased concentration of toxic metals $\mathrm{Cr}, \mathrm{Ni}, \mathrm{Mn}$ and other, it may result in phytotoxic effects, reduce plant yields, toxic metals can be accumulate in plant biomass (Shallari et al., 1998; Fernandez et al., 1999; Rajapaksha et al., 2012; Hetath et al., 2015). When the higher concentration of $\mathrm{Cd}, \mathrm{Cu}$ and $\mathrm{Zn}$ in the soil was detected, the correlation between their concentration in plants and soil were not estimated (Shallari et al., 1998). Other authors (Fernández et al., 1999) point out that this correlation exists.

The aim of the research was to investigate the influence of ground and granular serpentinite produced from miningderived serpentinite waste on the soil agrochemical properties, its phytotoxicity to spring barley, the influence on spring barley plant biomass and its chemical composition.

\section{MATERIALS AND METHODS}

The studies of serpentinite influence were carried out in 2016 at Agrochemical Research Laboratory of the Lithuanian Agrarian and Forestry Centre. Vegetative tests were carried out using Mitčerlich type growing vessels - plastic pots with holes on the bottom and a plate underneath them. Growing vessel had a diameter of $11.5 \mathrm{~cm}$, a height of $7.0 \mathrm{~cm}$ and an area of $0.02 \mathrm{~m}^{2}$. Growing vessels were randomly arranged on the test table with four replications. Each vessel was filled with $0.56 \mathrm{~kg}$ of soil, which was well mixed, vegetation residues removed, sieved through a $10 \mathrm{~mm}$ sieve.

The soil used in the research - loam, deep-layed soaked soil - PLB-g4 (Endohypogleyi - Eutric Planosol - PLe$g l n-W)$ was taken from Agroecological centre organic farm of Aleksandras Stulginskis University 0-20 cm humus soil layer, $\mathrm{pH}-5.1$, plant-derived $\mathrm{P}_{2} \mathrm{O}_{5}$ and $\mathrm{K}_{2} \mathrm{O}-190.0$ and 124.0 , total calcium $(\mathrm{Ca})$ - 1968, total and plant-derived magnesium $(\mathrm{Mg})$ - 617.0 and 18.9, Fe-3983, Cu-2.63, B-0.30, Co-0.23, Zn-12.0, Mn - 127.0, Cd - 0.054, Cr - 6.23, Ni 3.03 and $\mathrm{Pb}-4.83 \mathrm{mg} \mathrm{kg}^{-1}$.

The $\mathrm{pH}$ of the soil was determined by the potentiometer in the $\mathrm{KCl}$ extract, the amount of mobile $\mathrm{P}_{2} \mathrm{O}_{5}$ and $\mathrm{K}_{2} \mathrm{O}$ Egner-Rimo-Domingo (A-L), B quantity by colorimetric with azomethine methods. The content of total calcium (Ca) and magnesium $(\mathrm{Mg})$ and plant derived magnesium $(\mathrm{Mg})$ was investigated according to LVP D-13: 2011, edition 1, Fe, Co, $\mathrm{Cu}, \mathrm{Zn}, \mathrm{Mn}$ according to ISO 11047: 1998, A, Cd according to ISO 11047: 1998, B, and Cr, Ni and Pb according to ISO 022036: 2008.

Studies were carried out with ground and granular serpentinite. Serpentinite break stone, formed after serpentinite mining and unsuitable for use in other areas, was crushed and milled by special mills, ground serpentine granulated. Serpentinite was extracted from the Caucasus Mountains at the foot of the Elbrus Mountain (Russia). Ground and granular serpentinite fertilizers were created at the Agroecological Centre of Aleksandras Stulginskis University in order to solve the problem of handling of serpentinite waste remaining after mining.

Chemical composition of ground serpentinite has been investigated in accredited laboratory Eurofins Polska SP.z.o.o. (Poland). It has been determined that the $\mathrm{pH}$ of the ground serpentinite $\left(\mathrm{H}_{2} \mathrm{O}\right)$ is 8.0 , the dry matter content is 99.3, the total organic carbon $(\mathrm{C})-2.10$, the total nitrogen $(\mathrm{N})-<0.10, \mathrm{CaO}-1.76, \mathrm{~K} 2 \mathrm{O}-<0.010, \mathrm{P} 2 \mathrm{O} 5-0.013, \mathrm{Mg}-$ $9.00 \%, \mathrm{Na}-140.0, \mathrm{~S}-130.0, \mathrm{Fe}-50,000, \mathrm{Al} 2 \mathrm{O} 3-3000, \mathrm{Mo}-<0.50, \mathrm{Zn}-15.0, \mathrm{~B}-44.0, \mathrm{~Pb}-32.0, \mathrm{Cd}-1.20, \mathrm{Cr}-530.0$, $\mathrm{Co}-76.0, \mathrm{Cu}-5.40, \mathrm{Mn}-820.0, \mathrm{Ni}-1500, \mathrm{Hg}-0.11 \mathrm{mg} \mathrm{kg}^{-1}$.

Ground serpentinite $\mathrm{pH}\left(\mathrm{H}_{2} \mathrm{O}\right)$ was determined conductometric according to EN 13037, dry matter gravimetricaccording to EN 13040, total organic carbon combustion (C) according to EN 13137, total nitrogen (N) according to EN 13654-1, Kjeldahl (titrimetry), $\mathrm{K}_{2} \mathrm{O}$ and $\mathrm{P}_{2} \mathrm{O}_{5}$ according to Methodenbuch der BGK e.V., ICP-OES, Na and S according to EN ISO 11885, Mo according to ICP-OES, $\mathrm{CaO}, \mathrm{Mg}, \mathrm{Al}_{2} \mathrm{O}_{3}, \mathrm{~Pb}, \mathrm{~B}, \mathrm{Cd}, \mathrm{Cr}, \mathrm{Fe}, \mathrm{Cu}, \mathrm{Mn}, \mathrm{Ni}, \mathrm{Zn}$ according to EN 13650 / EN 11855 / acc. Meth. buch BGK e.V., ICP-OES, Co according to EN ISO 11885, ICP-OES, Hg by CV-AFS.

Experimental scheme: 1) unfertilized, 2) fertilized with ground serpentinite, 3) fertilized with granular serpentinite. The rate of ground and granular serpentinite in the growing vessel equals the serpentinite $\mathrm{Mg}_{250}$ norm per ha. Ground and granular serpentinite was mixed with soils. 
The plants of the spring barley 'Ema DS' (Lithuania) were grown. It was sown 20 spring barley seeds per pot. Vegetative studies from the time of common barley sowing to plant slicing the stem growth period lasted 28 days. Each experiment variant had four replications, artificial lighting was used. Barley was watered manually, taking into account the moisture content of the substrate surface.

The germination of spring barley seeds was determined for phytotoxicity testing, and on $28^{\text {th }}$ day, - number of surviving plants and average plant green mass (Baumgarten, Spiegel, 2004).

After cutting spring barley plants were weighed and determined the green mass of the spring barley plants; after drying - the dry matter content and the dry mass from the growing vessel. The agrochemical composition of the soil and the chemical composition of spring barley dry matter were determined after the experiment.

The content of calcium and magnesium in plant dry matter determined according to Directive 71/250 / EEC, magnesium content - according to Directive 73/46 / EEC, content of Fe, Cu, Zn, Mn in accordance with Directive 78/633 / EEC, quantity of Cd and Pb according to LST EN 15550 : 2008, Cr and Ni content - according to LST EN 15621: 2012.

The research data were evaluated applying the ANOVA method (Clewer, Scarisbric, 2001).

\section{RESULTS AND DISCUSSION}

Investigation of the mineral serpentinite influence on soil agrochemical properties revealed that the $\mathrm{pH}$ value increased significantly by $0.18-0.30$ units after application of serpentinite, and the soil became more alkaline. Ground serpentinite was significantly more effective in reducing the soil's acidity than granular. Along with the influence of serpentinite, the amount of total calcium (Table 1) increased significantly from 165.50 to $170.00 \mathrm{mg} \mathrm{kg}^{-1}$ in the soil. An increase in calcium content in soil was one of the reasons why soil acidity decreased and the soil became more alkaline. Serpentinite is rich in calcium (Bonati et al., 1984; Fernández et al., 1999; Harrison, Rajakaruna, 2001; Deschamps et al., 2012), and this affects the accumulation of calcium in the soil. The grinding of serpentinite effectively influenced the soil $\mathrm{pH}$ value because calcium distributed more uniformly in the soil and the granular serpentinite had to decompose at the beginning and therefore had a lesser influence on the change of soil acidity.

Table 1. The influence of ground and granular serpentinite on soil $\mathrm{pH}$, plant-derived phosphorus, potassium and magnesium, and total calcium, iron and magnesium content in the soil

\begin{tabular}{|c|c|c|c|c|c|c|c|}
\hline Treatment & $\mathrm{pH}$ & $\begin{array}{c}\text { Plant-derived } \mathrm{P}_{2} \mathrm{O}_{5} \\
\mathrm{mg} \mathrm{kg}^{-1}\end{array}$ & $\begin{array}{c}\text { Plant-derived } \\
\mathrm{K}_{2} \mathrm{O} \mathrm{mg} \mathrm{kg}^{-1}\end{array}$ & $\begin{array}{c}\text { Total } \\
\mathrm{Ca} \\
\mathrm{mg} \mathrm{kg}^{-1}\end{array}$ & $\begin{array}{c}\text { Total Fe } \\
\mathrm{mg} \mathrm{kg}^{-1}\end{array}$ & $\begin{array}{c}\text { Total } \\
\mathrm{Mg} \\
\mathrm{mg} \mathrm{kg}^{-1}\end{array}$ & $\begin{array}{c}\text { Plant-derived } \\
\mathrm{Mg} \\
\mathrm{mg} \mathrm{kg}^{-1}\end{array}$ \\
\hline Unfertilised & 5.05 & 198.75 & 122.20 & 626.75 & 3951.50 & 574.25 & 20.38 \\
\hline $\begin{array}{c}\text { Fertilised with ground } \\
\text { serpentinite (Mg250) }\end{array}$ & 5.35 & 205.50 & 117.43 & 792.25 & 7279.75 & 951.00 & 30.00 \\
\hline $\begin{array}{c}\text { Fertilised with granular } \\
\text { serpentinite (Mg250) }\end{array}$ & 5.23 & 198.25 & 116.00 & 796.75 & 7298.50 & 802.20 & 25.43 \\
\hline LSD05 & 0.05 & 24.75 & 9.30 & 53.76 & 515.42 & 130.41 & 0.75 \\
\hline
\end{tabular}

As a consequence of the effect of serpentinite, observed the significant increase of total iron content by 3328.25 $3347.00 \mathrm{mg} \mathrm{kg}^{-1}$ compared to unfertilised soil. The influence of ground and granular serpentinite on the amount of total iron in the soil was similar and no significant differences were found. The increase in iron content can be explained by the fact that the serpentinite itself was ferrous. As a result of the influence of serpentinite on soil, the total amount of magnesium was 227.95-376.75 mg kg-1 and plant-derived 5.05-9.62 mg kg-1. Serpentinite is a magnetically rich mineral (Fernández et al., 1999; Harrison, Rajakaruna, 2001; Deschams et al., 2011, 2012, Pekarskas, Šapranauskas, 2017), which is the reason for the increase of soil magnetism. Ground serpentinite increased the total and plant-derived magnesium content in soil more than granular serpentinite. Magnesium in the form of ground serpentinite was easier to release than granulated, and as a result, the amount of plant-derived magnesium increased in the soil. Application of serpentinite had little effect on changes in plant -derived phosphorus and potassium in soil. Serpentinite is not rich in phosphorus and potassium and could not have a greater influence on this elements content in the soil.

Investigating the effect of serpentinite on the amount of trace elements copper, zinc and manganese in the soil, it was estimated that the influence of serpentinite in soil significantly decreased the copper content by $0.12-0.18 \mathrm{mg} \mathrm{kg}^{-1}$ in soil. The amount of copper was lowered more by granular than by the ground serpentinite, but the decrease in copper content was insignificant. Because of the effect of serpentinite also decreased amount of zinc and manganese, but the decrease was insignificant (Table 2) compared to unfertilised and fertilised with ground and granular serpentinite soils. A significant amount of copper, zinc and, in particular, manganese was introduced into the soil with serpentinite, but these elements hardly released from serpentinite and did not increase its amount in the soil.

Table 2. The influence of ground and granular serpentinite on the content of trace elements and heavy metals in soils

\begin{tabular}{|c|c|c|c|c|c|c|c|}
\hline Treatment & $\begin{array}{c}\mathrm{Cu} \\
\mathrm{mg} \mathrm{kg}\end{array}$ & $\begin{array}{c}\mathrm{Zn} \\
\mathrm{mg} \mathrm{kg}^{-1}\end{array}$ & $\begin{array}{c}\mathrm{Mn} \\
\mathrm{mg} \mathrm{kg}^{-1}\end{array}$ & $\begin{array}{c}\mathrm{Pb} \\
\mathrm{mg} \mathrm{kg}^{-1}\end{array}$ & $\begin{array}{c}\mathrm{Cr} \\
\mathrm{mg} \mathrm{kg}^{-1}\end{array}$ & $\begin{array}{c}\mathrm{Cd} \\
\mathrm{mg} \mathrm{kg}^{-1}\end{array}$ & $\begin{array}{c}\mathrm{Ni} \\
\mathrm{mg} \mathrm{kg}^{-1}\end{array}$ \\
\hline Unfertilised & 2.64 & 13.70 & 135.50 & 4.69 & 5.63 & 0.063 & 2.59 \\
\hline Fertilised with ground serpentinite $\left(\mathrm{Mg}_{250}\right)$ & 2.52 & 13.63 & 127.75 & 5.21 & 5.91 & 0.062 & 4.75 \\
\hline Fertilised with granular serpentinite $\left(\mathrm{Mg}_{250}\right)$ & 2.46 & 13.40 & 132.00 & 5.03 & 5.74 & 0.063 & 3.78 \\
\hline LSD05 & 0.10 & 0.99 & 15.98 & 0.26 & 0.33 & 0.002 & 1.17 \\
\hline
\end{tabular}


Under the influence of serpentinite the amount of lead, chrome and nickel increased in soil, but it had little effect on the amount of cadmium in the soil. The lead and nickel amount increased in the soil significantly by $0.34-0.52$ and $1.19-2.16 \mathrm{mg} \mathrm{kg}^{-1}$, there was no significant increase in chromium amount. Only the tendency was observed that the amount of chromium in the soil increased under the influence of serpentinite. The serpentinite insertion form, when compared ground serpentinite to granular, did not have a significant influence on lead, chromium and nickel content, but only the tendency was observed that ground serpentinite increased lead, chromium and nickel content more than granulated (Table 2). This can be explained by the fact that a significant amount of these elements is introduced into the soil with the serpentine (Morrey et al., 1989; Schallari et al., 1998; Fernández et al., 1999; Deschamp et al., 2011, 2012), but separate elements unevenly releasing from the mineral. Grounding increases releasing, but it is not so significant.

Investigating the influence of ground and granular serpentinite on the germination of spring barley seeds and the number of plants during their stem elongation phase (BBCH 31-33) cutting from growing vessels, it was found that the ground and granular serpentinite reduced seed germination, but effect was negligible. Seed germination was further reduced by ground serpentinite than granular, and during the stem elongation phase, their influence on the number of spring barley plants in the growing vessel was the same (Table 3). This can be explained by the fact that in soil with high levels of toxic substances emerge the physiological mechanisms that tolerate metallic toxicity and prevent their absorption (Baker, 1981; Baumgarten, Spiegel, 2004).

Table 3. Influence of ground and granular serpentinite on the germination of spring barley seeds and on the survival of plants during their vegetation, $\%$

\begin{tabular}{|c|c|c|}
\hline Treatment & $\begin{array}{c}\text { 7 days after sowing } \\
(\mathrm{BBCH} 09-10)\end{array}$ & $\begin{array}{c}\text { After the cutting of spring barley plants } \\
\text { (BBCH 31-33) }\end{array}$ \\
\hline Unfertilised & 98.75 & 98.75 \\
\hline Fertilised with ground serpentinite $\left(\mathrm{Mg}_{250}\right)$ & 96.25 & 96.25 \\
\hline $\begin{array}{c}\text { Fertilised with granular serpentinite } \\
\left(\mathrm{Mg}_{250}\right)\end{array}$ & 97.50 & 96.25 \\
\hline LSD $_{05}$ & 6.61 & 6.45 \\
\hline
\end{tabular}

Application of serpentinite was effective for cultivated spring barley. It was found that the yield of green and dry mass of spring barley plants was increased due to the influence of serpentinite 0.049-0.256 and 0.011-0.046 $\mathrm{g}$ or 0.653.41 and $1.19-2.59 \%$ of the growing vessel, but this increase was insignificant. The amount of dry matter in the green barley mass increased in $0.12-0.26 \%$ compared to the unfertilized spring barley. The use of ground serpentinite significantly increased dry matter in the green biomass compared to unfertilized barley, while no significant differences were observed applying granular serpentinite (Table 4). Plant nutrients in serpentine (Bonati et al., 1984; Harrison, Rajakaruna, 2001; Hanly et al., 2005; Pekarskas et al., 2017) promoted the growth of spring barley biomass, resulting in higher yields of green and dry mass, and increased amount of dry matter.

Table 4. Influence of ground and granular serpentinite on the spring barley 'Ema $D S^{\prime}$ yield of green and dry mass and dry matter content

\begin{tabular}{|c|c|c|c|}
\hline & $\begin{array}{c}\text { Green mass yield g in } \\
\text { growing vessel }\end{array}$ & $\begin{array}{c}\text { Dry mass yield g in } \\
\text { growing vessel }\end{array}$ & Dry matter \% \\
\hline Unfertilised & 7.512 & 0.755 & 10.05 \\
\hline Fertilised with ground serpentinite $\left(\mathrm{Mg}_{250}\right)$ & 7.768 & 0.801 & 10.31 \\
\hline Fertilised with granular serpentinite $\left(\mathrm{Mg}_{250}\right)$ & 7.561 & 0.766 & 10.17 \\
\hline LSD $_{05}$ & 0.442 & 0.050 & 0.239 \\
\hline
\end{tabular}

The yield of the green and dry mass was higher applying ground serpentinite compared to the application of granular serpentinite, and the dry matter was significantly higher compared to the unfertilised spring barley plants. Grounding of serpentinite makes easier and faster nutrients uptake for spring barley than from granular serpentinite form. Application of ground serpentinite results in significantly higher amount of available nutrients than fertilizing with granular serpentinite. Studies have shown that ground and granular serpentinite is not phytotoxic to spring barley.

Serpentinite had a significant influence on the chemical composition of spring barley plants. Under the influence of ground serpentinite, more of calcium and iron but less of potassium and magnesium were accumulated in plants as compared to unfertilized soil. Fertilisation with serpentinite did not stimulate the accumulation of magnesium in plants, its amount decreased. Comparing the influence of ground and granular serpentinite, it was found that the accumulated amount of calcium, potassium and magnesium due to ground serpentinite was higher than that of granular serpentinite. The plants absorbed them more from the ground serpentinite form than from the granular, where the plants had more available nutrients. Plants have accumulated very similar amounts of iron in dry mass (Table 5).

Fertilising both with ground and granular serpentinite in the plants dry matter significantly reduced the content of the trace elements copper and manganese, and the amount of zinc decreased only after the application of granular serpentinite. Comparing the influence of ground and granular serpentinite, copper and zinc significantly decreased after application of ground serpentinite, while manganese accumulation was not significantly affected.

Serpentinite did not promote the accumulation of copper, zinc and manganese in plants. The grounding of serpentinite increases the mobility and availability of chemical compounds to plants. Comparing the effect of ground serpentinite on the accumulation of these elements in plants with granular, it was established that the influence of ground serpentinite on the plants resulted in significantly higher concentrations of copper and zinc. 
Table 5. The influence of ground and granular serpentinite on the spring barley 'Ema $D S^{\prime}$ dry matter chemical composition

\begin{tabular}{|c|c|c|c|c|c|c|c|}
\hline Treatment & $\begin{array}{c}\mathrm{K} \\
\%\end{array}$ & $\begin{array}{c}\mathrm{Ca} \\
\mathrm{mg} \mathrm{kg}^{-1}\end{array}$ & $\begin{array}{c}\mathrm{Mg} \\
\mathrm{mg} \mathrm{kg}^{-1}\end{array}$ & $\begin{array}{c}\mathrm{Fe} \\
\mathrm{mg} \mathrm{kg}^{-1}\end{array}$ & $\begin{array}{c}\mathrm{Cu} \\
\mathrm{mg} \mathrm{kg}^{-1}\end{array}$ & $\begin{array}{c}\mathrm{Zn} \\
\mathrm{mg} \mathrm{kg}^{-1}\end{array}$ & $\begin{array}{c}\mathrm{Mn} \\
\mathrm{mg} \mathrm{kg}^{-1}\end{array}$ \\
\hline Unfertilised & 4.53 & 7943.0 & 3076.0 & 132.0 & 6.04 & 26.7 & 189.0 \\
\hline Fertilised with ground serpentinite $\left(\mathrm{Mg}_{250}\right)$ & 4.51 & 8531.0 & 2836.0 & 187.9 & 5.13 & 26.7 & 144.0 \\
\hline Fertilised with granular serpentinite $\left(\mathrm{Mg}_{250}\right)$ & 3.96 & 6773.0 & 2415.0 & 199.0 & 4.87 & 20.7 & 151.0 \\
\hline LSD05 & 0.37 & 221.45 & 123.65 & 24.21 & 0.16 & 4.23 & 12.32 \\
\hline
\end{tabular}

Serpentinite significantly reduced the amount of heavy metals lead, chromium and cadmium, but significantly increased the amount of nickel in dry matter of barley plants. Comparing the influence of ground and granular serpentinite on the accumulation of heavy metals in barley dry matter, it was found significant reduction of lead and significant increase in chromium after the application of granular serpentinite, and the form of the serpentinite had no influence on amount of cadmium and nickel (Table 6).

Table 6. The influence of ground and granular serpentinite on the heavy metals amount in spring barley dry matter

\begin{tabular}{|c|c|c|c|c|}
\hline Treatment & $\begin{array}{c}\mathrm{Pb} \\
\mathrm{mg} \mathrm{kg}^{-1}\end{array}$ & $\begin{array}{c}\mathrm{Cr} \\
\mathrm{mg} \mathrm{kg}^{-1}\end{array}$ & $\begin{array}{c}\mathrm{Cd} \\
\mathrm{mg} \mathrm{kg}^{-1}\end{array}$ & $\begin{array}{c}\mathrm{Ni} \\
\mathrm{mg} \mathrm{kg}^{-1}\end{array}$ \\
\hline Unfertilised & 0.060 & 5.73 & 0.058 & 1.74 \\
\hline Fersilised with ground serpentinite $\left(\mathrm{Mg}_{250}\right)$ & 0.043 & 3.70 & 0.041 & 4.42 \\
\hline Fersilised with granular serpentinite $\left(\mathrm{Mg}_{250}\right)$ & 0.018 & 4.60 & 0.045 & 4.45 \\
\hline $\mathrm{LSD}_{05}$ & 0.009 & 0.51 & 0.011 & 0.14 \\
\hline
\end{tabular}

Serpentinite has not stimulated and blocked the accumulation of lead, chromium and cadmium in plants, but increased the amount of nickel. The accumulation of heavy metals in plant biomass was dependent on the form of serpentinite. The accumulation of Ni in plants was observed in studies in various countries (Morrey et al., 1989; Shallari et al., 1998).

\section{CONCLUSIONS}

The soil was becoming an alkaline due to the influence of ground and granular serpentinite, processed out of serpentinite break stone from the mining area; significant increased amounts of calcium, iron, total and plant-derived magnesium, lead and nickel, and substantially reduced amount of copper. Serpentinite had no effect on the amount of phosphorus and potassium, zinc, manganese, chromium and cadmium in the soil. The influence of ground serpentinite on the soil was much more alkaline compared to the granular, with a significant increase in plant-derived magnesium.

The yield of spring barley green and dry mass was higher applying ground serpentinite compared to granular, and dry matter was found to be significantly higher compared to unfertilized spring barley plants. Grounded and granulated serpentinite was not phytotoxic to spring barley.

The use of ground serpentinite increased accumulation of calcium, potassium and magnesium in the dry matter of the barley than the application of granular serpentinite. Application of serpentinite did not stimulate the accumulation of magnesium in plants, its amount decreased. Ground and granular serpentinite reduced the amount of trace elements as copper and manganese in the dry mass of the plant, and the amount of zinc decreased only after fertilization with granular serpentinite. Due to the effect of serpentinite on the dry matter of barley plants, lead, chrome and cadmium decreased significantly, but significantly increased nickel content.

\section{REFERENCES}

1. Andreani, M., Grauby, O., Muňzon, M. 2008. Occurrence, composition and growth of polyhedral serpentine. European Journal of Mineralogy, Vol. 20, pp. 159-171.https://doi.org/10.1127/0935-1221/2008/0020-1801

2. Baker, A. J. M. 1981. Accumulators and excluders - strategies in the response of plants to heavy metals. Journal of Plant Nutrition, Vol. 3, Iss. 1-4, pp. 643-654.https://doi.org/10.1080/01904168109362867

3. Baumgarten, A., Spiegel, H. 2004. Phytotoxicity (Plant Tolerance). Viena: Agency for Health and Food Safety.

4. Bonatti, E., Lawrence, J. R., Morandi, N. 1984. Serpentinization of oceanic peridotites: Temperature dependence of mineralogy and boron content. Earth and Planetary Science Letters, Vol. 70, pp. 88-94.https://doi.org/10.1016/0012-821X(84)90211-5

5. Boudier, F., Baronnet, A., Mainprice, D. 2010. Serpentine Mineral Replacements of Natural Olivine and their Seismic Implications: Oceanic Lizardite versus Subduction-Related Antigorite. Journal of Petrology, Vol. 51, Iss. 1-2, pp. 45-51. https://doi.org/10.1093/petrology/egp049

6. Chittenden, E. T., Stanton, D. J., Watson, J., Donson, K. J. 1967. Serpentine and dunite as magnesium fertilizer. New Zealand Journal of Agricultural Research, Vol. 10, No. 1, pp. 160-171.https://doi.org/10.1080/00288233.1967.10423088

7. Clewer A.G., Scarisbrick D.H. 2001. Practical statistics and experimental design for plant and crop science. New York, USA.

8. Deschamp, F., Guillot, S., Godard, M., Andreani, M., Hattori, K. 2011. Serpentinites act as sponges for fluid-mobile elements in abyssal and subduction zone environments. Terra Nova, Vol. 23, Iss. 3, pp. 171-178. https://doi.org/10.1111/j.1365$\underline{3121.2011 .00995 . x}$ 
9. Deschamps, F., Godard, M., Guillot, S., Chauvel, C., Andreani M , Hattori, K., Wunder, B., France L. 2012. Behavior of fluidmobile elements in serpentines from abyssal to subduction environments: Examples from Cuba and Dominican Republic. Chemical Geology, Vol. 312, pp. 93-117

10. Fernández, S., Seoane, S., Merino, A. 1999. Plant heavy metal concentrations and soil biological properties in agricultural serpentine soils. Soil Science and Plant Anglysis, Vol. 30, Iss. 13-14, pp. 1867-1884.https://doi.org/10.1080/00103629909370338

11. Hanly, J. A., Loganathan, P., Currie, L. D. 2005. Effect of serpentine rock and its acidulated products as magnesium fertilisers for pastule, compared with magnesium oxide and Epsom salts, on a Pumice Soil. 1. Dry matter yield and magnesium uptake. New Zealand Journal of Agricultural Research, Vol. 48, No. 4, pp. 451-460.https://doi.org/10.1080/00288233.2005.9513679

12. Harrison, S., Rajakaruna, N. 2001. Serpentine: the evolution and ecology of a model system, University of California Press.

13. Hattori, K. H., Guillot, S., 2003. Volcanic fronts form as a consequence of serpentinite dehydration in the forearc mantle wedge. Geology, Vol. 31, pp. 525-528. https://doi.org/10.1130/0091-7613(2003)031<0525:VFFAAC >2.0.CO;2

14. Hattori, K. H., Guillot, S., 2007. Geochemical character of serpentinites associated with high- to ultrahigh-pressure metamorphic rocks in the Alps, Cuba, and the Himalayas: Recycling of elements in subduction zones. Geochemistry, Geophysics, Geosystems, Vol. 8, Iss. 9, pp. 2-27. https://doi.org/10.1029/2007GC001594

15. Herath, I., Kumarathilaka, P., Navaratne, A., Rajakaruna, N., Vithanage, M. 2015. Immobilization and phytotoxicity reduction of heavy metals in serpentine soil using biochar. Journal of Soils and Sediments, Vol. 15, Iss. 1, pp. $126-138$. https://doi.org/10.1007/s11368-014-0967-4

16. Ilyina, V. P., 2013. Ceramic heat-insulation materials basar on serpentinite. Glass and Ceramics, Vol. 70, Iss. 7-8, pp. 285-288. https://doi.org/10.1007/s10717-013-9562-1

17. Lee, J-K., Soh, J-S. 2016. Performance of Magnesia Cement Using MgCO3 and Serpentine. Journal of the Korean Ceramic Society, Vol. 53, Iss. 1, pp. 161-121. https://doi.org/10.4191/kcers.2016.53.1.116

18. Mažvila, J. 1998. Lietuvos dirvožemių agrocheminès savybės ir jų kaita. Akademija, Kèdainių r. [In Lithuania]

19. Mažvila, J., Staugaitis, G., Vaišvila, Z., Aleknavičius, P., Juozokas, A., Mockevičius, R., Lukšienė, L. 2011. Lietuvos žemės našumas. Akademija, Kèdainių r. [In Lithuania]

20. Morrey, D. R., Balkwill, K., Balkwill. M-J. 1989. Studies on serpentine flora : Preliminary analyses of soils and vegetation associated with serpentinite rock formations in the south-eastern Transvaal. South African Journal of Botany, Vol. 55, Iss. 2, pp. 171-177. https://doi.org/10.1016/S0254-6299(16)31203-0

21. Pekarskas, J., Gavenauskas, A., Balkelis, L. 2017. Granuliuoto mineralo serpentinito ịtaka bulvių derliui, jo cheminei suděčiai ir dirvožemio savybėms. 23-osios tarptautinès mokslinès-praktinès konferencijos „Žmogaus ir gamtos sauga 2017“ medžiaga, pp. 148-151, Aleksandro Stulginskio universitetas. [In Lithuania]

22. Pekarskas, J., Šapranauskas L. 2017. Granuliuoto mineralo serpentinito ịtaka vasariniams kviečiams. 23-osios tarptautines mokslinès-praktinès konferencijos „Žmogaus ir gamtos sauga 2017“ medžiaga, pp. 132-135. [In Lithuania]

23. Rajapaksha, A. U., Vithanage, M. Oze, C., Bandara, W., Weerasooriya, R. 2012. Nickel and manganese release in serpentine soil from the Ussangoda Ultramafic Complex, Sri Lanka. Geoderma, Vol. 189, pp. 1-9. https://doi.org/10.1016/j.geoderma.2012.04.019

24. Roemheld, V., Kirkby, E. A. 2007. Magnesium functions in crop nutrition and yield. The International Fertilizer Society Proceedings, Vol. 616, pp. 4-23.

25. Shallari, S., Schwartz, C., Hasko, A., Morel, J. L. 1998. Heavy metals in soils and plants of serpentine and industrial sites of Albania. The Science of the Total Environment, Vol. 209, pp. 133-142. https://doi.org/10.1016/S0048-9697(98)80104-6

26. Senbayram, M., Gransee, A., Wahle, V., Thiel, H. 2015. Role of magnesium fertilisers in agriculture: plant-soil continuum. Crop \& Pasture Science, Vol. 66, pp. 1219-1229. https://doi.org/10.1071/CP15104

27. Skinner, H. C. W. 2005. The Web of Magnesium. International Geology Review, Vol. 47, Iss. 11, pp. 1111-1119. https://doi.org/10.2747/0020-6814.47.11.1111

28. Staugaitis, G., Vaišvila, Z. 2015. Inovatyvūs dirvotyros ir agrochemijos mokslo sprendimai. Kaunas. [In Lithuania]

29. Tenthorey, E., Hermann, J. 2004. Composition of fluids during serpentinite breakdown in subduction zones: Evidence for limited boron mobility. Geology, Vol. 32, Iss. 10, pp. 865-868. https://doi.org/10.1130/G20610.1

30. Verbruggen, N., Hermans, C. 2013. Physiological and molecular responses to magnesium nutritional imbalance in plants. Plant and Soil, Vol. 368, Iss. 1, pp. 87-99.https://doi.org/10.1007/s11104-013-1589-0 